\title{
Environmental Art Design Based on Ecological Philosophy Perspective
}

\author{
Ying Wei \\ College of Art and Design, Wuchang Institute of Technology, Wuhan, Hubei,30065, China
}

\begin{abstract}
Keywords: Ecological philosophy, Environmental art design, Harmony
\end{abstract}
\begin{abstract}
The rapid development of industrial civilization to a certain extent, caused serious environmental pollution and ecological damage, causing people to come to realize the importance of protecting the ecological environment, the environmental art design gradually infiltrated certain ecological concepts. In this paper, a brief analysis of environmental art design content and ecological concepts on the basis of the basic features, from an ecological point of view on the current environment concept art design of a systematic inquiry, hoping to promote the new era of environmental art design to meet the aesthetic needs of the community basis, can produce certain ecological environmental effects, prompting environmental art and design to achieve the effect of the harmonious development of man and nature.
\end{abstract}

\section{Introduction}

From the last century to today's society, the actual industrial civilization has been very rapid development in the production and life changing community, to enhance the people's quality of life, but also on the environment caused some damage, resulting in the gradual deterioration of the ecological environment, on the survival and development of mankind in the future to produce serious adverse effects. In this social context, the public come to realize the importance of environmental protection work, ecological awareness began formal awakening, even in the 1980s after the concept of sustainable development has been formally proposed, in various production areas of society, sustainable development the eco-friendly philosophy have been practicing a certain extent. Based on this, environmental art and design are also beginning to pay attention to the application of eco-design concept, based on further development work has been the promotion of environmental protection, ecological environment designed to promote environmental protection get more people's identity, promoting the concept of ecological practices and further development.

\section{Basic connation of environmental art design}

Environmental art design is a comprehensive concept, which includes a specific environment, art and design content and three aspects of the connotation of environmental art and design parsed not only to the three aspects of each functional orientation to be clear, but also to know the important link between the three.

\section{Definition of environment}

Everyone in the community are living in a particular environment, where the environment represents a huge space, including the space plants and animals, humans, and other environmental factors and so on. People living in this space, relying on the survival and development of space-acquired must have all kinds of substances, and the use of space in the link between the various elements and combinations to seek new development opportunities. However, people now live in an environment which is bound by the specific impacts and environmental constraints, while a certain extent, changed the original appearance of the environment. At this stage, the definition of environmental connotations are mainly two aspects, namely untapped original ecological resources and the environment, is to obtain a basis for sustainable human development; to be manually processed human environment, the living environment is the people of the current principal , and the community's production and life there is an extremely close relationship [1]. So in order to practice the basic national policy of environmental protection in the process of development of the artificial environment should permeate the concept of ecological, reducing the maximum damage artificial 
environment for the development of the natural environment, promote sustainable development of society.

\section{Environmental art connotation}

Environmental art as an art form in itself has some special significance, must contain the unique beauty of art and elegant, so environmental art can be defined as: based on natural, through appropriate transformation, the use of other means of basic environment Construction to further meet the needs of the community tangible and intangible aspects of the proposed environmental reform, so that people can enjoy while living in this environment-specific aesthetic, generate a new aesthetic experience [2]. Therefore, environmental art and design process should respect nature, the relationship between man and nature, maximum coordination between the organic combination of art and construction materials, to enhance the environment of the art, so that the environment and the natural landscape of artificial elements in perfect coordination.

\section{Basic conception of environmental art design}

Environmental art design specifically refers within a certain range of space environment art design and development, and in the actual development process should specifically analyze the relationship of other elements in the main building, public facilities and spaces, and then a reasonable selection, control costs, carrying capacity of the environment to implement reasonable analysis, synthesis of these materials for scientific planning, the final function in ensuring environment, based on the maximum aesthetic design to enhance the environment and achieve harmony between man and nature.

\section{Integrate essential characteristic of ecological idea into environmental art design}

Ecology originally proposed by German scientists in the late 1960s, its main contents of the types of relationships between organisms and the external environment, emphasizing the human development process should respect nature, and nature harmonious development. In the current environment, ecology concept art designs permeate the basic performance characteristics of the following aspects. First, efficiency. Simply put, efficient concept of ecological environment is to design and build process should be the maximum to avoid the waste of resources, positive change in the traditional extensive design and construction mode, to achieve internal resources by analyzing the relationship between the different elements comprehensive utilization, to minimize the cost of resources to get the most benefit. Second, the persistent. Mainly the concept of ecological sustainability in the body layout structure and associated facilities specific design environment art and design aspects, this feature requires the designer to the environment in the process of artistic conception and design should start from human needs of sustainable development, taking into account survival and development of human offspring need. Third, the diversity. The concept of ecological diversity features simple tube that environmental art related product design, designers hope in particular the design process to ensure the diversity of products, providing a wide range of choices for consumers, prompting consumers to active consumption, thereby further expand the scope of urban ecological environment, reduce environmental build pressure [3]. Fourth, cyclical. Cyclical simply means that construction in the process of making artificial environment related production materials for recycling, and allowed to self-decomposition and digestion, improve energy efficiency. In environmental design practice, ensure the use of relevant energy and final decomposition of pollutants to form a relatively closed network system, to achieve recycling of resources and maintaining ecological balance.

\section{Basic countermeasures to implement environmental art design under ecological idea perspective}

Affected by industrial society sustainable development in today's environment of worsening social situation, in order to promote the construction of a sustainable society in the current era background, environmental art and design must be adequate penetration of ecological philosophy, ecological philosophy sight By design and construction, and then gradually increase the environmental design of 
ecological, human nature and artistry, ensure environmental design of indoor and outdoor sections harmonization provide humanity with a more comfortable, harmonious and sustainable living environment for contribution corresponding force sustained and healthy development of society.

\section{Indoor environmental art design in ecological idea}

In essence, indoor environmental art and design in the current background should be under the guidance of the concept of ecological design for human life and living indoor living space for artistic design process, and this process needs to ensure that the design of naturalness and ecology, to maintain harmony between man and nature. In actual operation:

First, the art design and construction of indoor ecological environment should be guaranteed to have the appropriate quality external architecture, namely, the basic ecological buildings. The so-called eco-building simply means that the building itself has a natural ecological environment must be coordinated with the main building of the surrounding environment, and architectural interior design has a good environmental regulation, in a certain spatial scale to promote people, the main building forming a harmonious relationship with the environment unity. At this stage, the existence of fundamental social and ecological construction has a few things in common, namely the use of non-private adobe walls, new environmentally friendly brick walls, solar energy and double insulating glass and other types in the construction process, it is possible in the current environmental pollution and minimize damage buildings caused by lower technical level, for people living in them to create a good ecological space. The existence of ecological architecture can provide a solid foundation for the art and design of indoor environment of space, in the course of the designers of the indoor environment of art and design and decoration, we can take advantage of these basic conditions, environmental design, reduce red decoration program, and effectively improve work efficiency and effectiveness.

Second, designers should change the traditional interior design. Traditional indoor environmental art and design thinking to cumbersome pile of mainly quality and aesthetic demands and requirements of modern life contrary, can not be effective for modern people to create a comfortable indoor living space [4]. Therefore, the designer should carefully analyze and understand modern society, people for simplicity and classic requirements of the indoor environment, through the use of minority and decoration materials with a reasonable, creating a different environment artistic effect, prompting people showing humane living conditions and artistic characteristics, highlight the fashion simple beauty of modern society. In recent years, within the domestic and international interior design have begun to strengthen emphasis on minimalist decor, and hope that through the proper process of penetration in the minimalist decor ideas to make the occupants produce an aesthetic freshness to the spirit of joy and satisfaction.

Finally, the designer during the design process of the indoor environment should also be utilization of the natural environment of light and air effects, and strive to create a healthy indoor living environment in which people lived during the more intimate nature, and natural harmony. In the specific design process, designers should pay attention to the use of eco-friendly decoration materials, avoiding hazardous materials cause some pollution to the indoor environment and even the threat to people's health and so on, to enhance the indoor environment designed to maximize security.

\section{Conduct outdoor environmental art design in ecological idea}

In the field of environmental art design, art design outdoor environment is another of the key elements, the designer through environmental design in order to truly create a positive and healthy living space, based on the rational design of the indoor environment, but also should ecological concept, the maximum guarantee of quality outdoor environmental art design, to promote indoor and outdoor form a harmonious ecosystem, build a healthy space for people's life and production. In actual operation, the outdoor environment art and design of urban land resources should first conduct scientific management and use of every inch of land in strict accordance with the concept of ecological processing, and then combined with the city's natural landscape for a part of the overall effect the environment should be designed to ensure the aesthetic effect and ecological urban landscape, prompting the construction of the main functions of the city into full play. Effect for the entire city construction and planning, because industrial development has brought enormous 
environmental pollution, it is possible to maintain a balance of urban ecological development of the ecological environment in urban construction and people's health and life, and more importantly, it can macroscopic aspects of urban pollution play a purifying effect on the environment can be within a small range of micro-adjustment, improve environmental quality, to promote urban environment closer to the natural space. Therefore, the main city of reinforced concrete construction, based on ecological concepts, designers can build some green belt in the free space of the main building, the roof terrace breeding-related plants, truly enhance ecological urban space to meet the community Volkswagen pursuit and return to nature, to promote the city to obtain the corresponding sustainable development.

Meanwhile, the staff of outdoor environmental art and design should also pay attention to the city's use of the existing natural conditions, combined with the natural landscape by the Environmental Art Design organic together to enhance the natural properties of the urban environment, the maximum to avoid the urban environment unnecessary damage. When the city during construction had to be large-scale transformation of the original natural landscape, be sure to fully analyze the micro-climatic conditions and the overall situation of the food chain within the scope of architectural space, avoid the improper operation may cause permanent damage to the ecological environment [5] . In the specific design process, designers can design in order to ensure their own to meet the needs of urban ecological construction and development should also strengthen the various types of plant diversity and indigenous knowledge, and thus may be ecological in the design and application of different plants service functions for evaluating the relative system, through the interaction between the species to be adjusted to the quality of the environment, to avoid the introduction of alien species undermine the overall balance of the building microenvironment, adverse effects on the development of people's lives. In addition, in order to ensure the quality of outdoor environmental art design, the designer should be reasonable overall landscape of urban planning, and pay attention to avoid the use of high cost and low quality of the landscape, try not to design some external gorgeous but poor practical work. Environmental art designer should maintain the ecological balance of the city, prompting sustainable human development as a starting point for artistic design, the maximum increase ecological outdoor environment, social, artistic practicality and human nature, etc., for the urban sustainable development appropriate safeguards, the real people in the city to create a positive and healthy living space.

\section{Conclusion}

Overall, permeate ecological concept has evolved into an inevitable trend of modern environmental art design art in the current environment. People of our time in the pursuit of high-quality, innovative in order to get life on the basis of sustained and healthy development, but also should pay attention to protect the environment, maintain the ecological balance of the city, prompting the harmonious development between man and nature, to enhance the overall quality of life on the basis of the, but also for the healthy development of the well-being of future generations.

\section{References}

[1] Wang Ping, Chen Wenfu. Ecological philosophy issue in environmental art design. Art \& Design Research,2013(5):51-54.

[2] Hu Danxia. On Ecological Environmental Art Design Idea. Construction technology and design,2015(30):256-256.

[3] Li Qi. On ecological philosophy issue in environmental art design. Beauty and age . City,2015(1):30-31.

[4] Ma Xiaomin. On ecological philosophy issue in environmental art design. Art Science and Technology. 2013,26(4):226. 
[5] Ouyang Shanghai. Environmental Art Design Inspiration ecological idea of urban image design. Science and technology communication,2014(19):131-131,123. 